\title{
Late Caddoan Occupation Along Cowhide Bayou: An Update on the Belcher Mound and Village Sites
}

Jeffery S. Girard

Northwestern State University of Louisiana

Follow this and additional works at: https://scholarworks.sfasu.edu/ita

Part of the American Material Culture Commons, Archaeological Anthropology Commons, Environmental Studies Commons, Other American Studies Commons, Other Arts and Humanities Commons, Other History of Art, Architecture, and Archaeology Commons, and the United States History Commons

Tell us how this article helped you.

This Article is brought to you for free and open access by the Center for Regional Heritage Research at SFA ScholarWorks. It has been accepted for inclusion in Index of Texas Archaeology: Open Access Gray Literature from the Lone Star State by an authorized editor of SFA ScholarWorks. For more information, please contact cdsscholarworks@sfasu.edu. 


\section{Late Caddoan Occupation Along Cowhide Bayou: An Update on the Belcher}

Mound and Village Sites

\section{Creative Commons License}

\section{(c) (1) \&}

This work is licensed under a Creative Commons Attribution-NonCommercial 4.0 International License 


\title{
LATE CADDOAN OCCUPATION ALONG COWHIDE BAYOU: AN UPDATE ON THE BELCHER MOUND AND VILLAGE Sites
}

\author{
Jeffrey S. Girard \\ Regional Archaeology Program \\ Northwestern State University of Louisiana
}

\section{Introduction}

In the early 1930s, a northwestern Louisiana farmer cleared an area along Cowhide Bayou near the small town of Belcher. As he attempted to level a rise with a slip, he encountered a human skeleton. Fortunately, although he continued work in the surrounding area, he left the rise alone. Dr. Clarence Webb heard of the find in 1936 and began a project that would continue more than 20 years. It resulted in what remains today as the most completely excavated and reported mound investigation in the Caddoan area (Webb 1959). Webb's work at the Belcher Site (16CD13) not only provided a remarkably detailed picture of the sequence of events relating to construction and use of a prehistoric mound, his analysis of the mound's stratigraphic layers also served to establish a ceramic chronology for northwestern Louisiana.

Webb's investigations focused on the mound itself. No residential area was identified in the immediate mound vicinity. Structures erected on the mound probably were specialized ceremonial buildings or residences of elite members of the society. Webb (1959:12), however, noted that "...scattered areas of refuse, fire-darkened soil, and sherds were found for one half mile downstream"... and plotted a village area on the aerial photo provided in the monograph (Webb 1959: Figure 3). This area later was recorded as a site (16CD103; Gulf South Research Institute 1975). We now refer to the village area as the Comegys site after the 


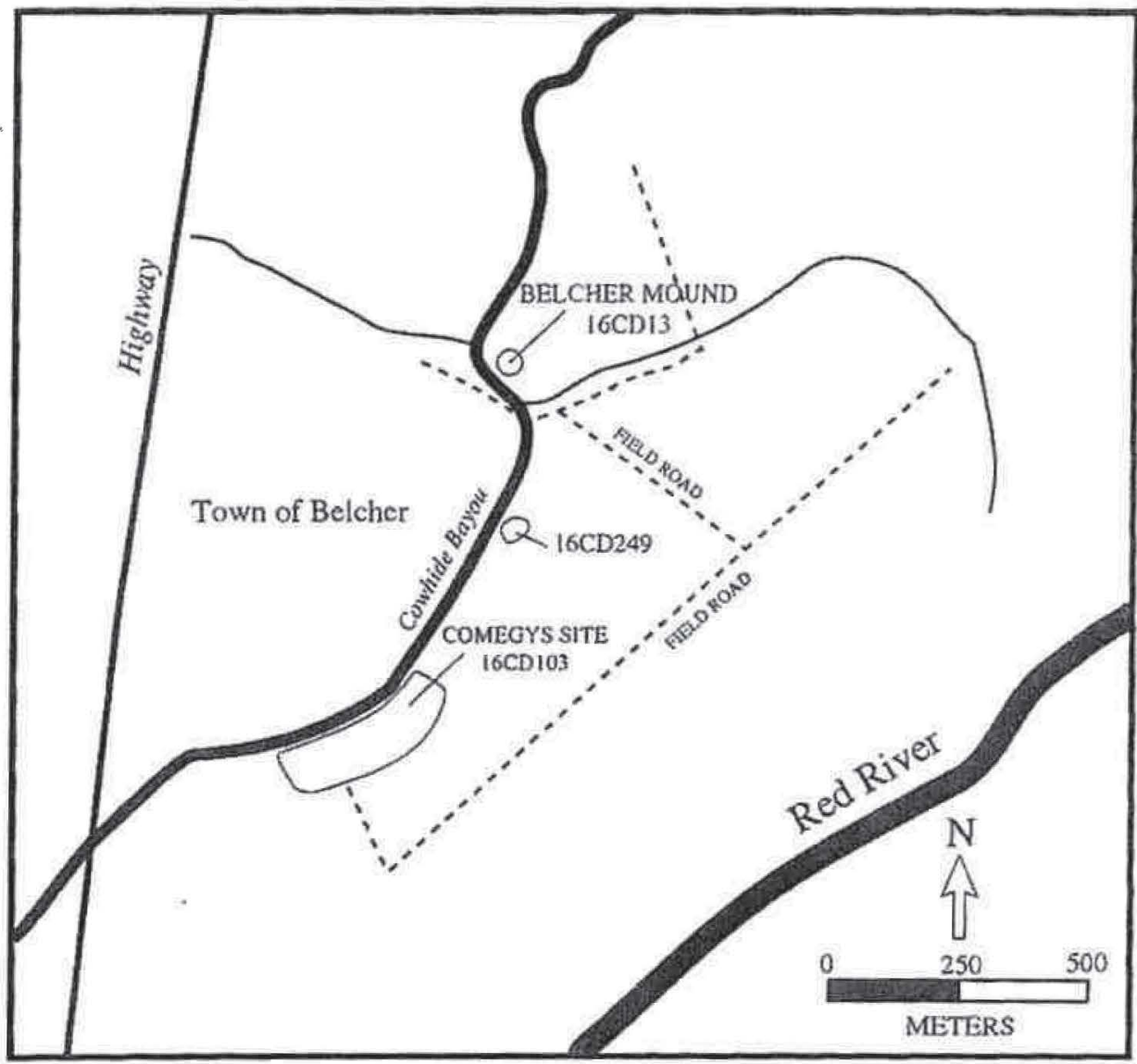

Figure 1. Locations of the Belcher Mound and Village Sites along Cowhide Bayou.

present landowner, William Comegys III. Mr. Comegys' grandfather was John Glassell, the landowner at the time of Webb's investigations and after whom Webb designated the ceramic type Glassell Engraved. In the spring of 1997, I recorded another small artifact scatter (16CD249) between the mound and Comegys site (Figure 1).

During the fall of 1998, Louis Baker of the Louisiana Archaeological Society and I returned to the area to conduct subsurface tests. The purpose of the project was to: (1) ascertain the nature of, and variation in, the subsurface deposits in both the mound and village areas; (2) find the former location of the mound; (3) search for buried cultural features at the village site; and (4) recover additional materials that would help determine the temporal range of occupation represented. 
Volume 10(3)

\section{Re-examination of the Belcher Mound Site (16CD13)}

\section{Field Investigations}

Webb (1959) presented detailed maps, aerial photographs, and descriptions of the mound location in his monograph. Despite this information, I was unable to find any trace of the former mound or habitation debris in the area during my initial visit in the spring of 1997. Baker and I returned to the area in the fall of 1998, however, and encountered a light scatter of sherds and chipped stone in a plowed field adjacent to Cowhide Bayou. We made a surface collection, then excavated four auger tests (Auger Test $1-4$ ) and two 50-x-50 cm test pits (Test Pits 1 and 2). Deposits consisted of yellowish red (5YR4/6) fine sandy loam that extended to a depth of 35 to $50 \mathrm{~cm}$ below the surface. At that level an abrupt change occurred to a dark reddish brown to black (5YR3/2 to 5YR2/1) silt loam. The dark deposit obviously is a buried soil and probably is contiguous with the "original midden surface" identified by Webb beneath the mound. Only three small sherds were recovered from the subsurface tests, all from the buried soil.

No evidence of the former mound was visible in the plowed area where the artifacts were found. After careful study of the photographs and maps in Webb's report, we concluded that the mound was located adjacent to the bayou in an area no longer plowed and now covered in dense vegetation. Two additional auger tests (Auger 5 and 6) were excavated in this area. Stratigraphy was found to be too complex to describe adequately with the auger data. However, a buried dark reddish brown $(5 \mathrm{YR} 3 / 2)$ stratum was encountered at $90 \mathrm{~cm}$ below surface in Auger 5 and $1.35 \mathrm{~m}$ below surface in Auger 6. A single incised sherd was recovered from this buried deposit in Auger 6 . The complexly stratified overburden likely represents the backfill from Webb's excavations with the buried soil being the underlying midden.

Although the limited testing indicated that few artifacts are associated with the buried surfaces, there is a significant possibility that buried features, including postholes relating to structures, exist in areas surrounding the mound. Webb's work was confined to the mound. It is possible that a situation similar to that around Mound $\mathrm{A}$ at the Early Caddoan period George C. Davis site (Newell and Krieger 1949; Story 1998) is present. Fortunately, the site is protected and remains in excellent condition.

\section{Investigations at the Comegys Site (16CD103)}

Artifacts are visible on the surface of the Comegys Site for approximately $300 \mathrm{~m}$ on the crest and upper slopes of the natural levee parallel to Cowhide Bayou. The scatter extends almost $50 \mathrm{~m}$ back from channel. Surface artifact densities are 


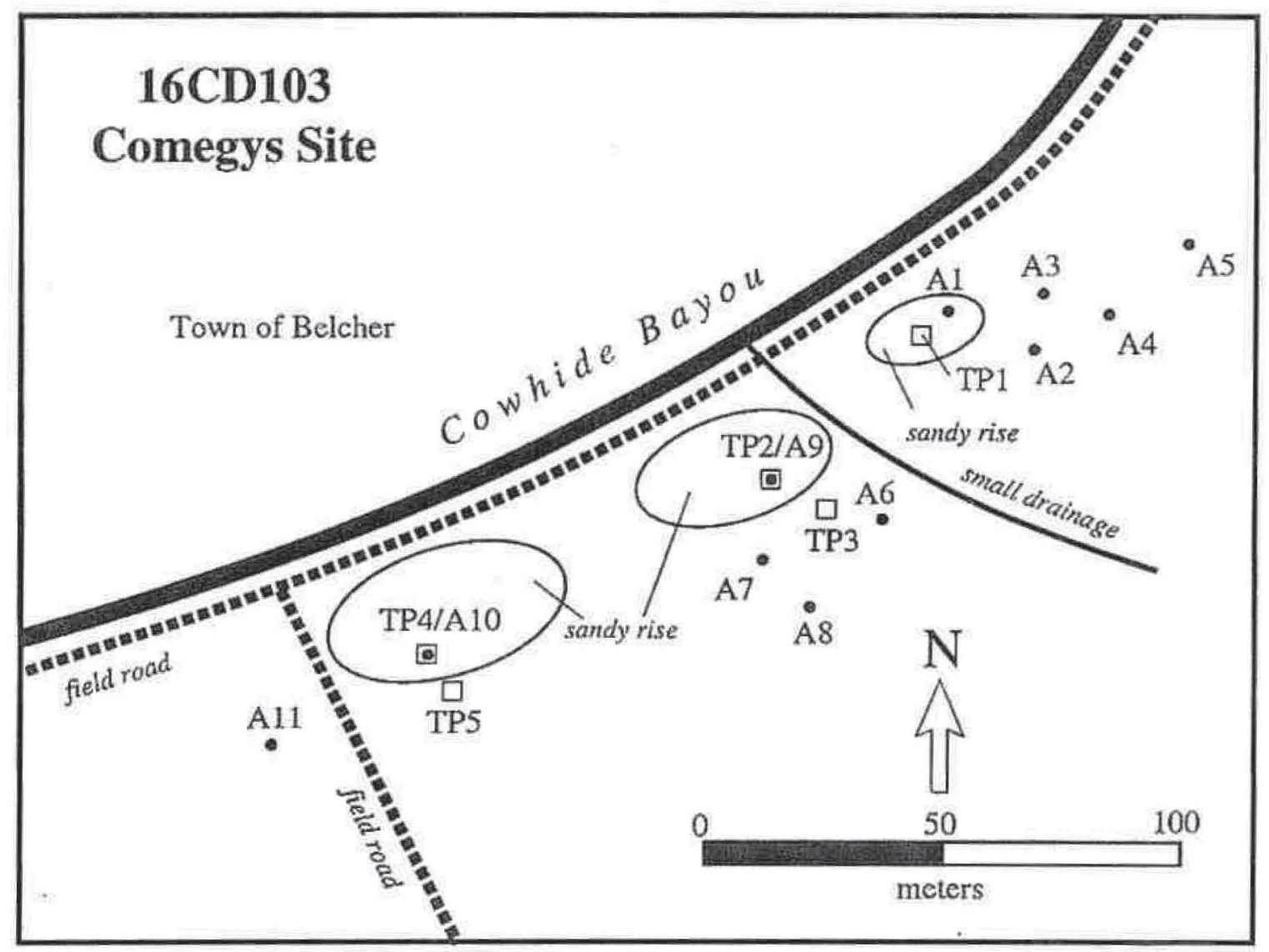

Figure 2. Sketch map of the Comegys Site Showing Locations of Auger Tests and Test Pits.

highest on three distinct sandy rises (Figure 2). The crest of the natural levee is fine sandy loam with silty clay loam on the upper backslope. Soils are mapped as Norwood silty clay loam, an entisol that covers many natural levees and point bars in the modern meander belt of Red River in northwestern Louisiana (Edwards et al. 1980). The site has been plowed and cultivated at least since the $1930 \mathrm{~s}$. A local informant told us that people have been collecting artifacts regularly from the site for at least the past 20 years.

\section{Auger Tests}

As an initial step in ascertaining the nature of the subsurface deposits, I excavated 11 auger tests into both the sandy rises and finer-grained deposits on the backslope. The tests indicate that the clay loam on the backslope overlies coarser natural levee sediments. The buried deposits were less than $30 \mathrm{~cm}$ deep near the crest of the natural levee, and as deep as $60 \mathrm{~cm}$ to the south (A8). No artifacts were recovered in the auger tests on the backslope. 
Fine sandy loam was present throughout the profiles on the sandy rises and a small number of artifacts were recovered to depths of $60 \mathrm{~cm}$. We decided to excavate a test pit into each of the rises to obtain a better understanding of the deposits and to test for buried features. Two additional units were placed just off the rises on the upper portion of the backslope.

\section{Test Pit 1}

The first unit was excavated on the smallest rise near the northeast end of the site. This is the only rise from which no artifacts were recovered in the auger test (A1). Deposits consisted of a dark reddish brown (5YR3/4) sandy loam in the upper $20 \mathrm{~cm}$. A few small flakes and sherds were recovered. Plow scars were visible in the third level and more homogeneous, brown (7.5YR4/4) sandy loam was present beneath. No artifacts were recovered beneath the plow zone. Excavation was stopped at $40 \mathrm{~cm}$ below surface. Other than the plow scars, no cultural features were encountered.

\section{Test Pit 2}

This unit was excavated on the middle sandy rise. Auger 9 revealed sandy loam deposits containing a small number of artifacts to a depth of $60 \mathrm{~cm}$. A 1-x-1 m unit was placed at the crest of the natural levee. The upper $15 \mathrm{~cm}$ consisted of a dark brown to dark reddish brown (57.5YR3/4) sandy loam plowzone (Figure 3). Patches of darker deposit (5YR3/2) were encountered at about $15 \mathrm{~cm}$. At approximately $20 \mathrm{~cm}$ below the surface an abrupt change to these darker deposits occurred throughout the unit - apparently a buried A horizon, the upper portion of which had been impacted by plowing. A gradual change to a brown (7.5YR4/4) fine sandy loam occurred by $35 \mathrm{~cm}$ below surface. A subtle color change to strong brown (7.5YR5/6) was visible beneath. Excavation was stopped at $75 \mathrm{~cm}$ below surface when artifacts no longer were being recovered. Densities were highest in the third level which sampled the top of the buried A horizon. No cultural features were noted.

\section{Test Pit 3}

We then decided to excavate a test unit through the backslope clay into the underlying sandy loam. We only screened a sample of the overlying clay, but this was sufficient to determine that it lacked cultural material. Only the upper 20 to 30 $\mathrm{cm}$ appeared disturbed by plowing. The clay extended 35 to $40 \mathrm{~cm}$ below the surface at which point there was an abrupt shift to a dark reddish brown (5YR3/4) very fine sandy loam or silt loam. A small number of sherds and flakes were recovered in the next $30 \mathrm{~cm}$. The test confirmed that the clay had been deposited after the site was occupied. The clay appears to thicken away from Cowhide Bayou and toward the modern Red River suggesting that it may have resulted from flooding of the modern river. A thin layer of clay may once have covered the sandy rises near the bayou, but the clay has become mixed with the underlying natural levee deposits in the plow zone. 


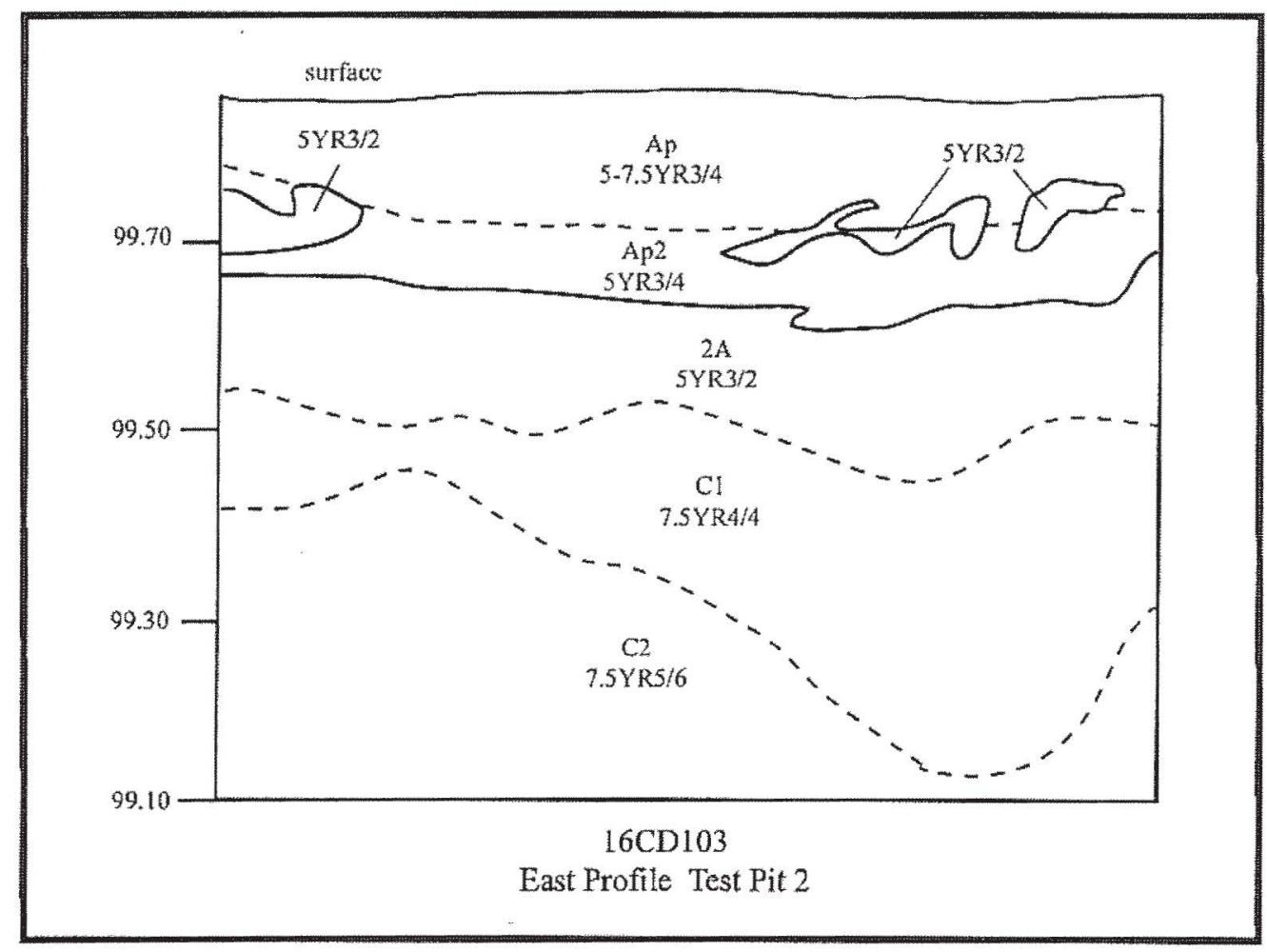

Figure 3. East Profile of Test Pit 2 at the Comegys Site.

\section{Test Pit 4}

Test Pit 4, another 1-x-1 m unit, was excavated on the western rise near the crest of the natural levee. We were interested in finding out whether or not the profile would be similar to that encountered in Test Pit 2, and to look for possible cultural features. The upper $10-15 \mathrm{~cm}$ was homogenous dark brown (7.5YR3/4) plow zone (or more accurately a disked zone). Underlying this was a zone of plow scars, alternating diagonal bands of dark reddish brown (5YR3/2 and 5YR3/4) fine sandy loam containing artifacts. A very abrupt change to a brown to yellowish red (5-7.5YR5/6) fine sandy loam occurred at about $25 \mathrm{~cm}$ below surface. It is apparent that deep plowing has completely gone through the buried A horizon, into the underlying $\mathrm{C}$ horizon in this area. Most artifacts were found within the banded zone; only a few small specimens were recovered in the underlying zone.

\section{Test Pit 5}

Because of the plow disturbances in Test Pit 4 , we decided to excavate one more unit off the edge of the sandy rise where a thin layer of clay overlay the midden surface. Two distinct components to the plowzone were noted (Figure 4). The upper deposit is regularly disked and contained coarser sediments, probably dragged over from the sandy rise. The lower portion was clay and had plow scars visible in other units. The dark reddish brown (5YR3/3-4), buried sandy loam surface appeared between 25 and $30 \mathrm{~cm}$ below the surface. Artifacts were more 


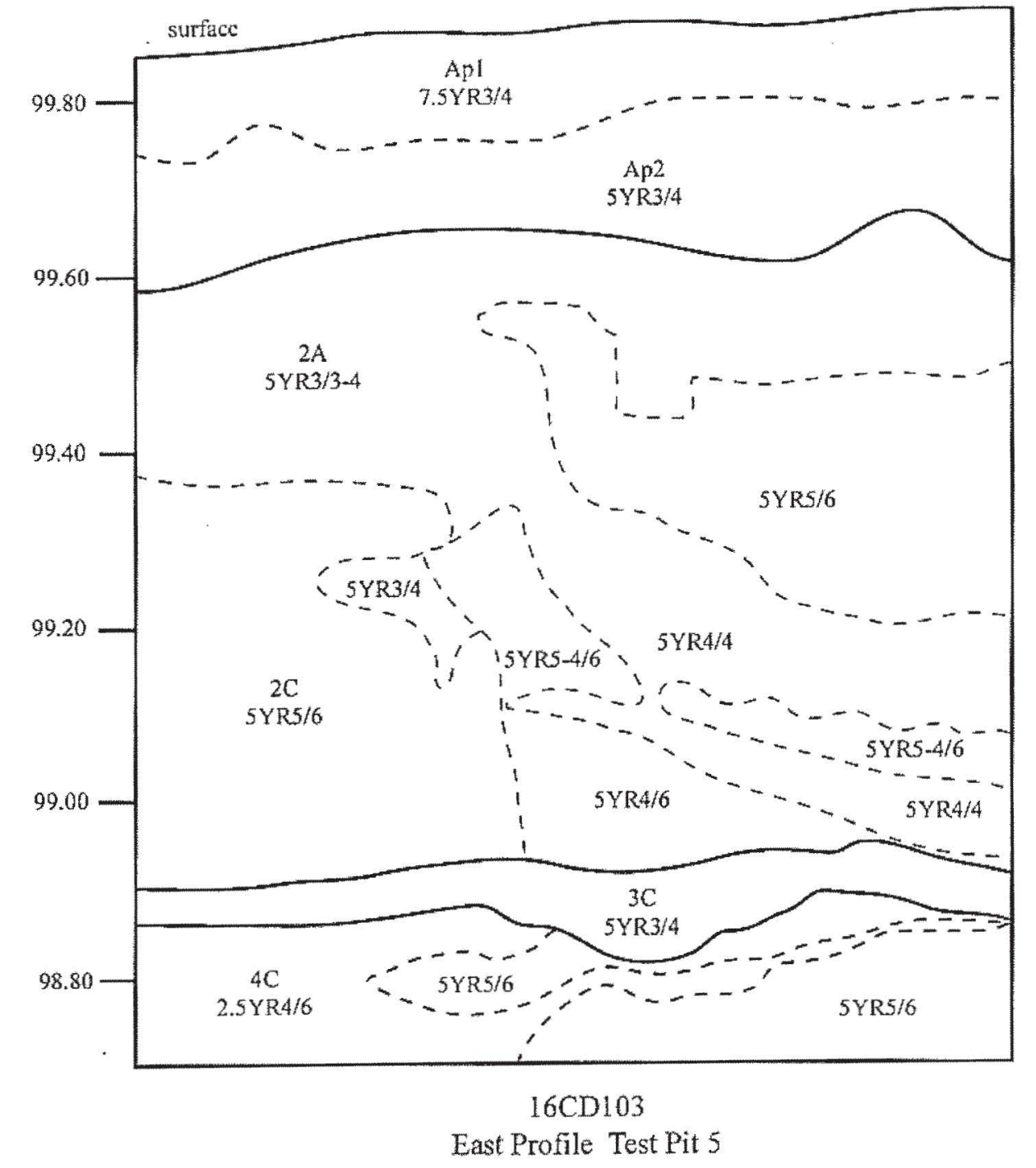

Figure 4. East Profile of Test Pit 5 at the Comegys Site.

numerous than in the other test units in the upper $20 \mathrm{~cm}$ of the buried deposit. We began to notice subtle color variation, particularly in the southeastern portion of the unit at about this level. Artifacts continued to be recovered, although in smaller amounts. Eventually it became clear that a pit had been dug into the deposits and back filled leaving a complex pattern of lenses. Lamella along some of the lens boundaries suggested that some fill washed back in. The lensing appar- 
ently is due to the $\mathrm{A}$ and $\mathrm{C}$ horizon deposits being mixed when the pit was backfilled. Although I cannot be certain, I think it likely that this is a historic feature, perhaps a treasure hunter's excavation. The fill apparently was not screened, however, as it contained artifacts.

At 65 to $70 \mathrm{~cm}$ below the top of the buried soil, an abrupt change in the deposits occurred throughout the unit. A dark reddish brown (5YR3/4) sandy loam, similar to the $2 \mathrm{~A}$ horizon in color and texture, was encountered. This stratum clearly represents a separate depositional event. The dark color suggested that the surface was sufficiently stable for an A horizon to develop. However, rather than fading gradually, another abrupt transition to lighter alluvial deposits occurred within 5 to $10 \mathrm{~cm}$ (thus on Figure $4 \mathrm{I}$ have designated it $3 \mathrm{C}$ rather than as another $\mathrm{A}$ horizon). The $3 \mathrm{C}$ and underlying $4 \mathrm{C}$ deposits did not contain artifacts or other evidence of human activity.

The Belcher village area (Comegys Site) has undergone significant disturbances. Plowing has gone through the midden on the crest of the natural levee; historic tenant farm occupations took place on the site; and treasure-hunting activities probably have caused subsurface disturbances. However, intact buried deposits are present and significant research potential remains.

\section{Description of the Recovered Artifacts}

\section{Sherds from the Belcher Mound Site}

Two of the nine recovered undecorated sherds from the Belcher Mound site have shell temper; the remainder are grog/grit tempered (Table 1). One of the brushed sherds is a rim with a flared lip. Brushing is diagonal and it is likely that the type Karnack Brushed is represented. The ridged specimen is a Belcher Ridged body sherd. Two diagonal incised sherds, both likely to be from necks of jars, were recovered. One body sherd has a single straight incised line. None of the incised sherds can be related to a specific type.

The engraved sherd from Test Pit 1 is an everted rim with shell temper. Surfaces are eroded but a curvilinear engraved line appears to be present. The design element cannot be ascertained. A shell-tempered engraved sherd also was recovered from the surface. The specimen has curvilinear and straight lines with red pigment. The second engraved sherd from the surface has grog temper and curvilinear lines. All of the engraved sherds are too small to relate to specific types.

The specimens fall within the range of sherds recovered by Webb from the mound excavations. The collection is too small to determine whether or not the entire temporal range of site occupation is represented. 
Volume 10(3)

Table 1. Classification of Sherds from the Belcher Mound Site.

\begin{tabular}{|lccccc|}
\hline & Surface & Auger 1 & Test Pit 1 & Auger 6 & Total \\
\hline \hline Undecorated & 8 & 1 & 0 & 0 & 9 \\
Brushed & 3 & 0 & 0 & 0 & 3 \\
Ridged & 1 & 0 & 0 & 0 & 1 \\
Incised & 2 & 0 & 0 & 1 & 3 \\
Engraved & 2 & 0 & 1 & 0 & 3 \\
\hline Total & 16 & 1 & 1 & 1 & 19 \\
\hline
\end{tabular}

\section{Sherds from the Comegys Site}

Undecorated: Almost $60 \%$ of the sherds recovered in the test pits are undecorated (Tables 2 and 3). Grog and grit temper is present in almost all specimens. Although no shell particles were visible, a few sherds have voids that may have resulted from leached shell. Mean sherd thickness is 6.458 (Std. Dev. $=1.626)$, well within the range of other Caddoan sites in the Red River floodplain in northwestern Louisiana. Only four undecorated rim sherds were recovered - one apparently from a bowl and another from a small jar with a short, flared rim. The two specimens recovered from the auger tests are too small to infer vessel forms. A 14$\mathrm{mm}$ thick, flat sherd from Test Pit 3 probably represents the base to a jar. As is the case in most plowed sites in the Red River floodplain, sherds tend to be small and little else can be ascertained regarding the forms of represented vessels.

Incised: Diagonal incised lines are present on five body sherds and two rim sherds. All of the body sherds are curved in a manner suggesting that they represent the neck area to jars with constricted necks.
The rim sherds (Figure $5 \mathrm{~F}$ ) probably are from similar vessels. Webb (1983:193) referred to similar specimens as a late variant of the type Dunkin Incised. He noted that in Early Caddoan period (ca. AD 1000-1200) contexts, Dunkin vessels tended to be cylindrical jars - the constricted neck, flared rim forms appear during the Middle Caddoan period (ca. AD 1200-1500; Webb's Bossier focus).

Only one horizontal incised sherd was recovered. This specimen also appears to represent the neck of a flared rim jar. Several types could be represented; most likely are Kiam Incised (punctated body) or Hardy Incised (undecorated body). The paucity of horizontal incised sherds probably is an indication that the site relates almost exclusively to the late Middle and Late Caddoan periods. Horizontal incised sherds are common in Early Caddoan period and most Middle Caddoan period contexts in the region (cf. Girard 1994). Curvilinear incising also is rare, represented by one body and one rim sherd. Both sherds are small and it is not possible to ascertain the represented design elements or vessel forms. 
Table 2. Classification of Body Sherds from the Comegys Site.

\begin{tabular}{|c|c|c|c|c|c|c|c|c|c|c|c|c|c|c|c|c|}
\hline & \multicolumn{2}{|c|}{ TPI } & \multicolumn{2}{|c|}{ TP2 } & \multicolumn{2}{|c|}{ TP3 } & \multicolumn{2}{|c|}{ TP4 } & \multicolumn{2}{|c|}{ Auger 9} & \multicolumn{2}{|c|}{ Auger 10} & \multicolumn{2}{|c|}{ TP5 } & \multicolumn{2}{|l|}{ Total } \\
\hline & $\#$ & $\%$ & $\#$ & $\%$ & $\#$ & $\%$ & $\#$ & $\%$ & $\#$ & $\%$ & $\#$ & $\%$ & \# & $\%$ & $\#$ & $\%$ \\
\hline Diagonal Incised & - & - & 2 & 4.0 & 1 & 6.7 & 1 & 2.7 & 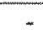 & - & - & - & 1 & 1.1 & 5 & 2.5 \\
\hline Horizontal Incised & - & - & 1 & 2.0 & - & - & - & - & - & - & - & - & - & - & 1 & 0.5 \\
\hline Curvilinear Incised & - & - & - & - & - & - & 1 & 2.7 & - & - & - & - & - & - & 1 & 0.5 \\
\hline Miscellaneous Incised & - & - & 2 & 4.0 & - & - & 2 & 5.4 & 1 & 50.0 & - & - & 13 & 14.0 & 18 & 9.0 \\
\hline Brushed & - & - & 3 & 6.0 & - & - & 1 & 2.7 & - & - & I & 50.0 & 2 & 2.2 & 7 & 3.5 \\
\hline Belcher Ridged & 1 & 50.0 & 4 & 8.0 & 2 & 13.3 & 7 & 18.9 & - & - & - & - & 13 & 14.0 & 27 & 13.4 \\
\hline Zoned Punctated & - & - & 1 & 2.0 & - & - & 1 & 2.7 & - & - & - & - & 1 & 1.1 & 3 & 1.5 \\
\hline Miscellaneous Punctated & - & - & 1 & 2.0 & 1 & 6.7 & - & - & - & - & - & - & 2 & 2.2 & 4 & 2.0 \\
\hline Red Slipped & - & - & - & - & 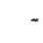 & - & 1 & 2.7 & - & - & - & - & - & - & 1 & 0.5 \\
\hline Engraved & - & - & 3 & 6.0 & - & - & 3 & 8.1 & - & - & - & - & 8 & 8.6 & 14 & 7.0 \\
\hline Undecorated & 1 & 50.0 & 3 & 6.0 & 11 & 73.3 & 20 & 54.1 & 1 & 50.0 & 1 & 50.0 & 53 & 57.0 & 120 & 9.7 \\
\hline Total & 2 & & 50 & & 15 & & 37 & & 2 & & 2 & & 93 & & 201 & \\
\hline
\end{tabular}

Table 3. Classification of Rim Sherds from the Comegys Site.

\begin{tabular}{|c|c|c|c|c|c|c|c|c|}
\hline & TP1 & $\mathrm{TP} 2$ & TP3 & $\mathrm{TP} 4$ & TP5 & Auger 9 & Auger 10 & Total \\
\hline Diagonal Incised & - & - & - & - & 2 & - & - & 2 \\
\hline Curvilinear Incised & - & - & - & - & 1 & - & - & 1 \\
\hline Belcher Ridged & - & - & - & - & 3 & - & - & 3 \\
\hline Engraved & - & - & 1 & 1 & 4 & - & - & 6 \\
\hline Undecorated & - & - & 1 & 1 & - & 1 & 1 & 4 \\
\hline Total & . & - & 2 & 2 & 10 & 1 & 1 & 16 \\
\hline
\end{tabular}

Eighteen body sherds have straight incised lines, but design elements or even line orientations cannot be ascertained. On most specimens multiple lines are present that are parallel and relatively closely spaced.

Brushed: Seven brushed body sherds were recovered. One specimen probably is from a short, flared rim (lip missing) of the form commonly found on Belcher Ridged vessels. The remaining sherds have brushing in a single direction and probably represent either Bossier Brushed or Karnack Brushed vessels.

Belcher Ridged: Thirty sherds can be assigned to the distinctive type Belcher Ridged. Most (27) are body sherds and have the low vertical ridges that are distinctive of the type. Unlike Pease Brushed-Incised sherds, all lack brushing between the ridges. Three rim sherds have vertical to slightly-diagonal, short, incised 


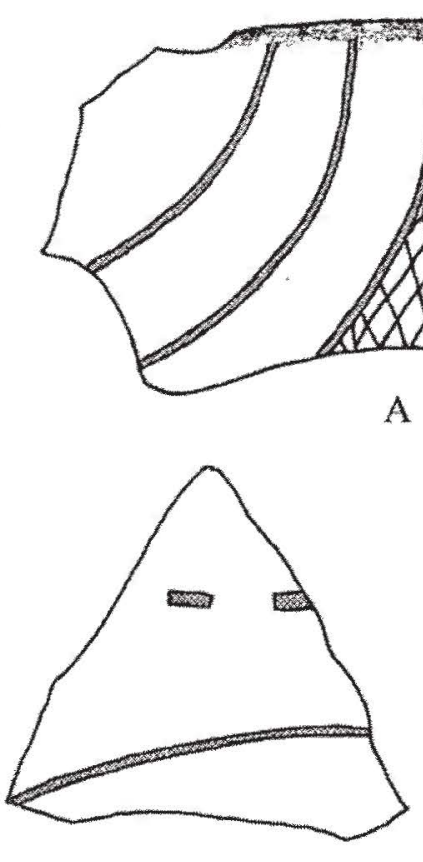

D

A
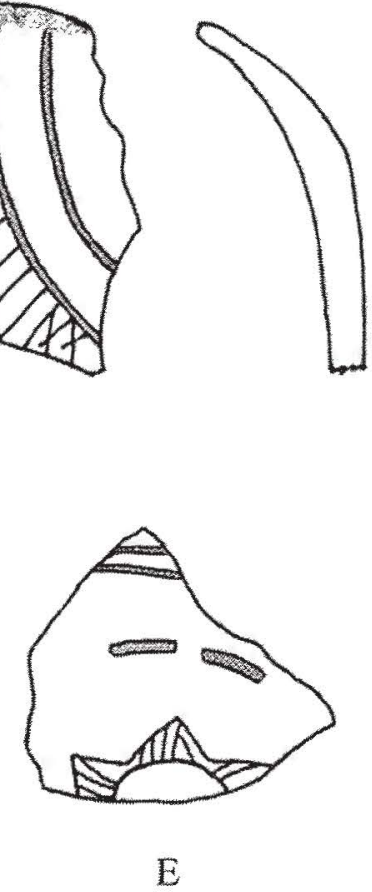

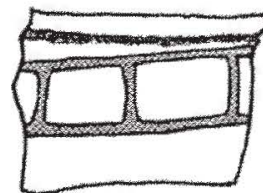

B

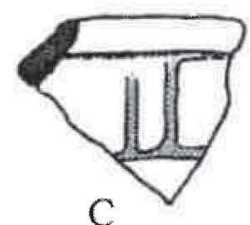

$\mathrm{C}$
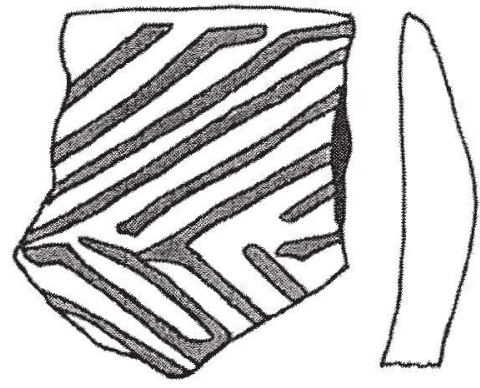

F

Figure 5. Selected Sherds from the Comegys Site: Avery Engraved (A), probable Glassell Engraved (B,C), Belcher Engraved (D,E), Dunkin Incised (F).

lines. The rims are small and sharply angled. This decoration and rim form is common on Belcher Ridged vessels (cf. Webb 1959:Fig. 113). No examples of the rolled rims found on many Belcher Ridged vessels were found at this site.

Punctated: Six sherds have punctations as the dominant decorative element. Three have incised lines enclosing zones filled with punctations. Lines are rectilinear on two (probably Pennington PunctatedIncised) and curvilinear on one (Crockett Curvilinear Incised). The other three sherds have punctations only. One sherd is large enough to ascertain that diagonal punctations are placed in horizontal rows. It is possible that this sherd represents the rim from a Foster Trailed-Incised vessel. Punctated elements are more commonly associated with Early and Middle Caddoan period contexts but small amounts were recovered by Webb (1959:Table 1) at the Belcher Mound (16CD13).

Red Slipped: One body sherd has a thin red slip over the exterior surface, Red slipped sherds are found in small numbers on Caddoan sites in the region. Only a small number of sherds and two vessel from the Belcher Mound (16CD13) had red-slipped surfaces (Webb 1959:157). 
Table 4. Classification of Stone Artifacts from the Comegys Site.

\begin{tabular}{|lrrrrrrr||}
\hline & TP1 & TP2 & TP3 & TP4 & TP5 & Auger 10 & Total| \\
\hline Cortical flakes & 1 & 39 & 8 & 32 & 59 & 2 & 141 \\
Interior flakes & 3 & 76 & 11 & 49 & 70 & 1 & 210 \\
Cores & 0 & 7 & 0 & 2 & 1 & 0 & 10 \\
Arrow points & 0 & 0 & 0 & 0 & 1 & 0 & 1 \\
Bifaces and fragments & 0 & 2 & 0 & 0 & 1 & 0 & 3 \\
Ground or grooved stone & 0 & 0 & 0 & 1 & 0 & 0 & 1 \\
Unmodified stone & 0 & 42 & 6 & 11 & 14 & 0 & 73 \\
\hline Total & 4 & 166 & 25 & 95 & 146 & 3 & 439 \\
\hline
\end{tabular}

Engraved: Fourteen body sherds and six rims have engraved decorations. Multiple parallel curvilinear lines are present on one rim and five body sherds. One body sherd appears to represent the shoulder from a Hickory Engraved bottle. Another probably relates to the type Belcher Engraved. Two other probable Belcher Engraved sherds are present. One has a single curved line with an adjacent dashed line (Figure 5D). Another with a dashed line and sun symbol is from a Belcher Engraved bottle (Figure 5E). Two rims and five body sherds have straight parallel lines and appear to be from carinated bowls. Two other rims, probably from carinated bowls, have sufficient remaining design elements to suggest that they relate to the type Glassell Engraved (Figure $5 \mathrm{~B}, \mathrm{C})$. The largest engraved sherd is a portion of the rim from an Avery Engraved jar (Figure 5A). The specimen is of sufficient size to determine that the rim diameter was $14 \mathrm{~cm}$. Decoration consists of parallel curvilinear lines forming $u$ shaped elements separated by crosshatched zones. A vessel with a similar rim is illustrated by Webb (1959:Figure120b) from the Belcher Mound (16CD13).

\section{Stone Artifacts from the Comegys Site}

All flakes and cores recovered from the excavations are made of local chert and fine-grained quartzite stream pebbles. No silicified wood, coarse-grained quartzite, or novaculite appear to be represented. One core, however, is of a honey-colored chert not common in local gravels.

Of the 351 recovered flakes, $141(40.2 \%)$ have cortex on their dorsal surfaces (Table 4), a relatively high percentage indicating the use of small pebbles. Chipping probably was directed at production of flakes for immediate use and occasional retouch into specific forms. Only one specimen had retouch scars on one edge. Cores tend to be small, fragmented, and are not numerous. All have flake scars struck from multiple platforms with no apparent attempt to thin or shape the outline.

A single arrow point was recovered (Figure 6C). The point, which came from Level 2 of Test Pit 5, is small and crudely chipped. The stem contracts slightly to a rounded base. It is possible that a Bassett form was intended, but the specimen lacks 
Volume 10(3)

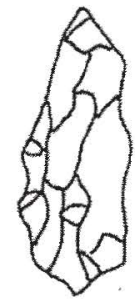

A

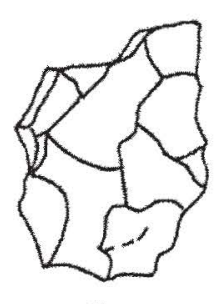

B

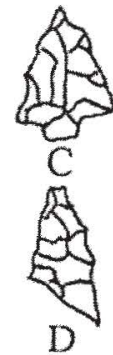

Figure 6. Retouched Stone Artifacts from the Comegys Site: Flake Blanks (A,B), Arrow Point (C), Distal Point Fragment (D).

the pointed stem and barbed shoulders usually associated with the type. Bassett points are the most common form at the Belcher Mound site and in other Late Caddoan period contexts in the region.

Only three other retouched specimens were recovered. One (Figure 6D), recovered from Test Pit 2 , is a narrow arrow point tip of local chert. Also recovered from Test Pit 2 is a flake blank, roughly oval in outline but broken distally (Figure 6B). Finally, recovered just above the $3 \mathrm{C}$ horizon in Test Pit 5, was a small lenticular biface (Figure 6A). The specimen is not well thinned and has obvious chipping errors (knot and step scarring). It was chipped either directly from a small chert pebble or from a thick flake. It likely represents a discarded blank, perhaps intended for an arrow point or a small Gary dart point.

One small tabular chunk of ferruginous sandstone recovered from Test Pit 4 has multiple narrow grooves apparently from use as an abrader.

Unmodified stone in the form of small chert gravels and concretions was recovered in all of the units except Test Pit 1 . One small chunk of pumice and two chunks of what appears to be limestone were recovered in Test Pit 4. It is possible that these relate to historic use of the area.

\section{Comments}

The primary goal of this project was to ascertain the nature of the subsurface deposits in both the mound and village areas. In the mound area, a buried soil was found 30 to $50 \mathrm{~cm}$ below the surface. The limited testing carried out indicated few artifacts are associated with this buried deposit. However, there is a significant possibility that buried features, including postholes relating to structures, exist in areas surrounding the mound.
The village area (Comegys site) has significant disturbances - plowing has gone through the midden on the crest of the natural levee; historic tenant farm occupations took place on the site; and treasure hunting activities probably have caused some subsurface disturbances. However, intact buried deposits are present and significant research potential remains. 
The second goal was to find the former location of the Belcher mound. Confirmation of the location will necessitate excavation of deep test pits. However, the auger tests reported here strongly suggest that the mound was located in the now brushy area adjacent to Cowhide Bayou.

The third goal was to search for buried cultural features at the village site. None were found. However, as noted earlier, the testing showed that intact midden deposits are buried on the backslope of the natural levee. This situation is excellent for preservation of features.

The final goal was to recover additional materials that would help determine the temporal range of occupation represented. Most recovered materials appear to relate to the Late Caddoan period. Particularly interesting is the paucity (three sherds were collected in 1997; none were recovered in the test pits) of Pease Brushed Incised, the major utilitarian type of the Middle Caddoan period in the region (cf. Girard 1997). If significant Middle Caddoan period occupation is represented, we would expect the type to be better represented. Use of the Comegys site appears to coincide primarily with the major construction episodes (Webb's Belcher III and IV) at the Belcher Mound.

Clarence Webb's investigations at the Belcher Mound provided some of the most important data on late prehistoric Caddoan lifeways recovered in northwestern Louisiana. The data will become increasingly important as more is learned about the local archaeological context of the mound.

\section{Acknowledgments}

Thanks to William Comegys III for permission and assistance in carrying out the fieldwork. The research that is the subject of this paper was conducted through the State of Louisiana's Regional Archaeology program, based at Northwestern State University of Louisiana. It has been financed with state funds and with federal funds from the National Park Service, U.S. Department of the Interior.

\section{References Cited}

Edwards, Jimmy P., George Martin, J.

Wayne Magoun, W. Wayne

Kilpatrick, and Charley Henry

1980 Soil Survey of Caddo Parish,

Louisiana. United States Department of Agriculture, Soil Conservation Service.

Girard, Jeffrey S.

1994 Regional Archaeology Program, 
Management Unit 1: Fifth Annual Report. Report on file at the Louisiana Division of Archaeology, Department of Culture, Recreation, and Tourism, Baton Rouge.

1997 Caddoan Settlement in the Red River Floodplain: Perspectives from the Willow Chute Bayou Area, Bossier Parish, Louisiana. Louisiana Archaeology 22:143-162.

Gulf South Research Institute

1975 Red River Waterway, Louisiana, Texas, Arkansas, and Oklahoma. Mississippi River to Shreveport, Louisiana, and Shreveport, Louisiana to Daingerfield, Texas. Design memorandum No. 15, Analysis, Volume 5: Archaeology, History, and Culture. Report on file at the Louisiana Division of Archaeology, Baton Rouge.
Newell, H. Perry and Alex D. Krieger 1949 The George C. Davis Site, Cherokee County, Texas. Society for American Archaeology Memoirs No. 4, Menasha.

Story, Dee Ann

1998 The George C. Davis Site: Glimpses into Early Caddoan Symbolism and Ideology. In The Native History of the Caddo, Their Place in Southeastern Archeology and Ethnohistory, edited by T.K. Perttula and J.E. Bruseth, pp. 9-43. Studies in Archaeology 30, Texas Archeological Research Laboratory, The University of Texas at Austin.

Webb, Clarence $\mathrm{H}$.

1959 The Belcher Mound, A Stratified Caddoan Site in Caddo Parish, Louisiana. Memoirs of the Society for American Archaeology No. 16, Salt Lake City. 